\title{
When you choose to be a Survivor, Testimony of Life!
}

\author{
*Jasmina Alexander \\ Republic of Panama, Panama University, USA
}

Submission: August 01, 2017; Published: August 02, 2017

*Correspondence Address: Jasmina Alexander, Panamá, República of Panama, Florida, USA, Email: jialexa@gmail.com

\section{Case Blog}

"My story as a life warrior began in February 2011, when I was a third year student, with 14 years of age, a girl with many dreams in life. I had beautiful hair and decided to cut it to donate it to children with leukemia and cancer. So I did, I cut it and I gave it. Later I began to feel pains in my legs, in the joints, I bothered a lot to walk and more to go up and down stairs. I felt tired all the time. My parents took me to the doctor and they did not give me what I had, until one night the pain was so unbearable that I had to be taken to the clinic, but unfortunately the doctor just left, so we returned home and stayed in return the next day. So it was done, leaving the school we went to with Dr. Germain Tegera, sent me x-rays and examinations of everything, to know what I had (Figure 1).

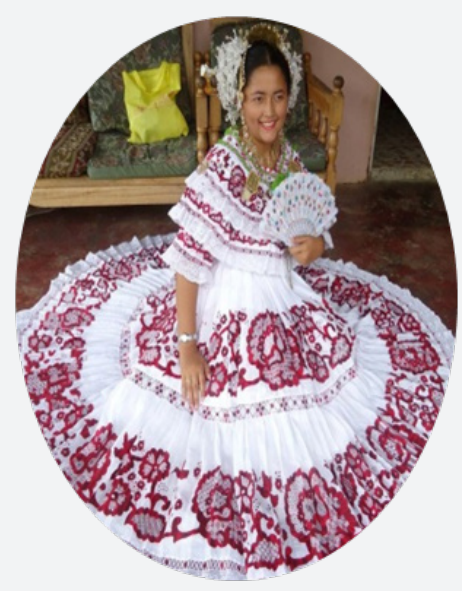

Figure 1: Larissa Rivera.

The next week, with the results ready, we went to the clinic; the doctor saw them beat in the mouth and mom and I looked at each other and then he said: Larissa's symptomatology is leukemia.... Automatically I started to cry and I asked: will my hair fall out? And he said: I do not know. Then he said: you will have a painful examination in the marrow to know if you actually have leukemia. We went home and my mother told my dad what the doctor had said. A few minutes later, the doctor's secretary called to tell us to be at the hospital the next day at the Rafael Estévez hospital, opening the doors for immediate attention. Everything was done as it is, I was hospitalized for a few days, after a series of tests decide to refer to Pediatric Specialties. There I had other tests to be able to hospitalize me. I was then given the bone marrow examination, the result of which was given to me on July 20,2011, which confirmed that I had Acute Lymphoblastic Leukemia (ALL). I started my treatments the next day, on July 21 of the same year. I got the catheter and they also transfused me since my hemoglobin had decreased and the white blood cells were very high. After 22 days hospitalized, I was given a way out.

Then I continued my treatment, in the external consultation of Pediatric Specialties, where one day, during one of my treatments, a young woman from the "PIDE UN DESEO" (Ask for a wish) foundation arrived and asked me: What wish would you like to make a reality? I told her I wanted to go to Disney ... I got the wish. That trip served me to give me encouragement, hope and joy in my journey against this disease. I am eternally grateful to them ... On the way back, I continued my treatment, my hair fell fast, everywhere I found strands, on the bed, on the chairs, on the pillow, on my brush, but none of this collapsed me because I was sure That someday my hair would grow again .... The treatments made me sick, every day I vomited sometimes I did not want to eat, but I did; My mother and my godmother insisted that I eat to be able to have strength since I was receiving a very strong treatment and I understood that I had to eat and drink water; That even if I did not taste it and knew I was wrong, I had to eat if I wanted to keep seeing the light at the end of the tunnel.

One of the treatments, the intrathecal, is a treatment in the spine, where I was asleep and placed a medication. Once finished, I felt pain, but just as I was going forward. I also received oral and intravenous chemotherapy, as well as radiation therapy. The latter was the one that determined that my head was completely without hair. I had 10 sessions in the column 
and 12 sessions in the head. On the day of the last session I rang the bell at the Instituto Oncológico Nacional, which meant that I had completed my radiation phase. That same day was my third year graduation, so at the end of the radiation, we left for Penonomé, my godmother ran like never before and I arrived on time (Figure 2).
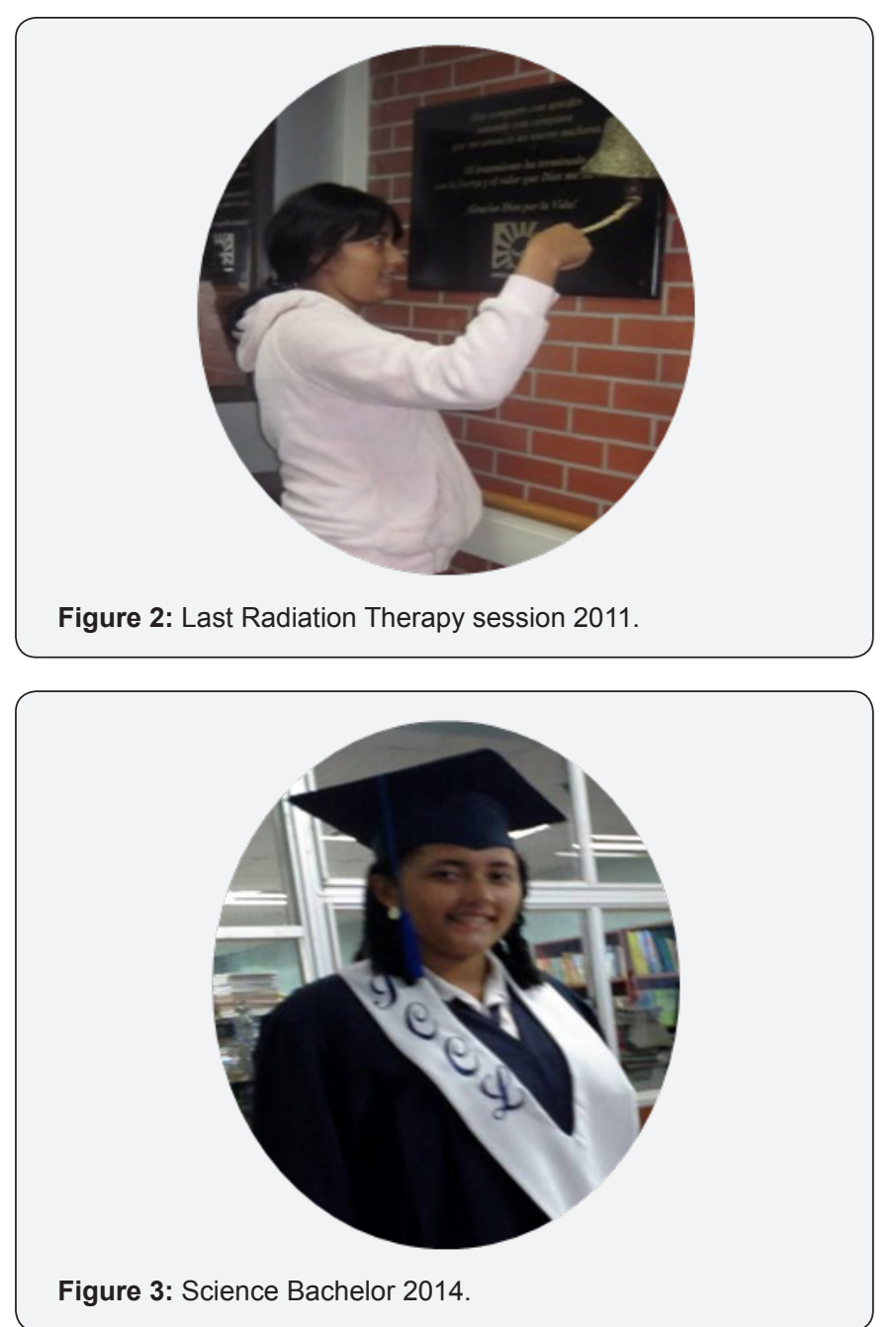

I had the pleasure of graduating with my classmates. I had been able to culminate through modules that I solved when I felt the urge to do homework. I am grateful to my colleagues, because despite everything we were very close and I know that we will continue being. I continued my studies with difficulties, but I continued ... 3 years later I graduated from high school in Science, then I chose to study Special Education and today I am in my third year. All this time I continued in my treatment and always keeping my faith high and the hopes of continuing to live. After spending more than 9 months in the capital, at my godmother's house, attending almost every day to treatment, I was able to return to Penonomé with my mother to continue them there. It was 3 long years, but thank God I'm clean today, but I continue to attend check-ups (Figure 3).

During this time I learned that life is one and we must take care of it and live each day as if it were the last. I urge all people who are going through a difficult illness, to go forward, to have faith, because the best doctor who has the cure for everything is God and for your treatment to work, you must feed well, even if you do not feel like it, but do it; Drink lots of water and take your medications on time. God gives you the weapon; you use it and defeat your opponent. For my treatment, my parents' support, my faith and the desire to continue living were fundamental (Figure 4). Thanks to all the people who raised prayers and to each of those who were always looking out for my health. And you know my warriors, TO WAR! BLESSINGS.

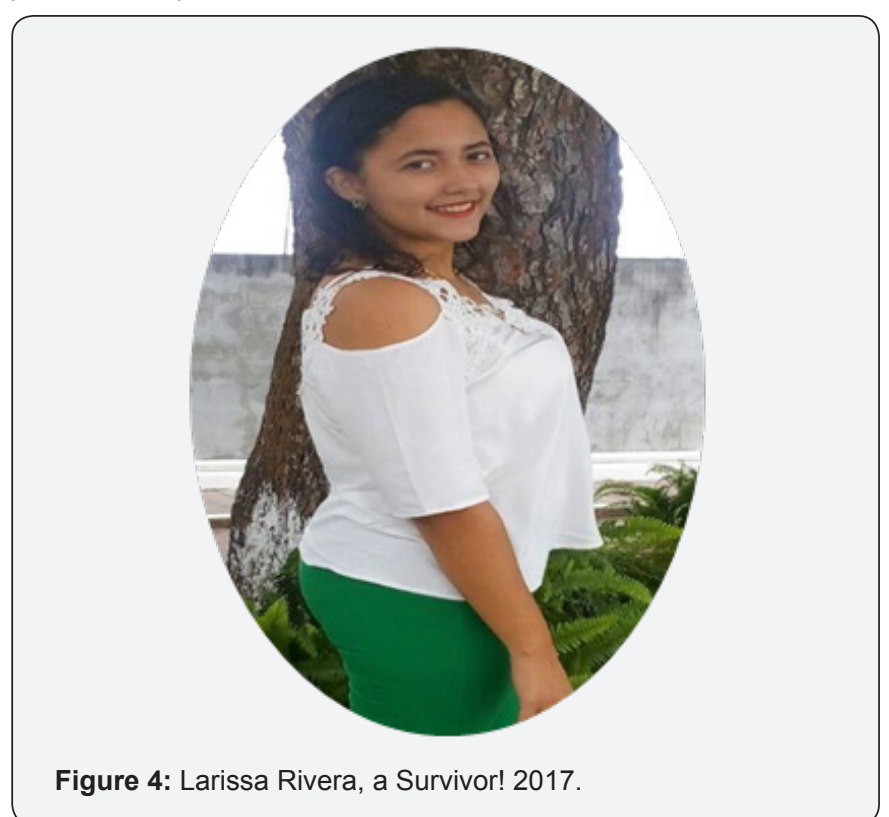

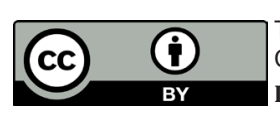

This work is licensed under Creative Commons Attribution 4.0 License DOI: 10.19080/CTOIJ.2017.06.555688

\section{Your next submission with Juniper Publishers will reach you the below assets}

- Quality Editorial service

- Swift Peer Review

- Reprints availability

- E-prints Service

- Manuscript Podcast for convenient understanding

- Global attainment for your research

- Manuscript accessibility in different formats ( Pdf, E-pub, Full Text, Audio)

- Unceasing customer service

Track the below URL for one-step submission https://juniperpublishers.com/online-submission.php 